\title{
Using Multiculturalism as a "New Way of Seeing the World": Ontario Aboriginal Educational Policy According to Foucault
}

\author{
Lorenzo Cherubini \\ Brock University \\ Ontario, Canada
}

By considering the Ontario First Nation, Métis, and Inuit Policy Framework (2007) from a Foucauldian perspective, this paper presents a policy discourse of knowledge, power, and identity from a multicultural education framework. Through Foucauldian theoretical perspectives, the paper creates alternate possibilities in confronting the ways to understand public educational policy considered the purpose of multicultural education. It invites teachers, administrators, district leaders, and policy makers to consider how educational policy in one Canadian province strategically situates Aboriginal peoples in a historical context, exercises Foucauldian notions of power and care, and potentially endorses the subjectification of Aboriginal peoples through recommendations of self-identification practices.

\author{
Contextual Framework \\ Theoretical Framework \\ Analysis \\ Implications and Recommendations \\ Conclusion \\ References
}

Multicultural policies and practices related to education in both the United States of America and Canada are an outcome of the challenges, political movements, and legislation that sought to underscore the distinct needs and learning preferences of students from varying races and cultures. The demographics of both countries have changed dramatically from only 40 years ago when, as an example, White students counted for nearly $80 \%$ of public school enrollment in the United States; currently the American Indian/Alaska Native population is predicted to increase by nearly $55 \%$ between 2000 and 2050, relative to the 9\% predicted growth of White Americans (Nieto, 2010). At present, there are over 640,000 American Indian/Alaska Native students enrolled in public and private kindergarten-to-grade12 schools across the United States. In Canada, there was a $28 \%$ increase in the Aboriginal population (compared to $6.2 \%$ of the mainstream population) between 2001 and 2006 (Statistics Canada, 2003; 2008). (It should be noted that the use of the all-inclusive word "Aboriginal" recognizes the socio-cultural diversity of all First Nation Peoples). Conversely, in Ontario (the province from which the respective Aboriginal educational policy 
under discussion emanates) there are over 50,000 Aboriginal students attending public school. While these and other statistics related to the respective growth of school populations are not justification for the heightened attention on multicultural policies, they do nonetheless provide a context for the emerging educational policies. Multicultural policies and practices have intended to create more respectful learning environments in public schools across the United States and Canada and to recognize institutional barriers that have historically impeded equal opportunities for all students (Lee, Menkart, \& Okazawa-Rey, 1998).

Multicultural practices are sensitive to the inherent connection between knowledge and power and how these two concepts manifest themselves in public schools (Apple, 2000). This is to recognize that the origins of knowledge and power in schools include a myriad of complexities that implicate upon an individual's compliance to the institution versus commitment to their professional roles. Indeed, the overriding purpose of multicultural education (and the central premise on which this paper is based) according to Ghosh and Abdi (2004) is "to create new possibilities in confronting the ways in which we see the world" ( $p$. 31). The competing voices of various ethnic and cultural groups, what Giroux (1991) refers to as the Eurocentric influence of "coloniz[ing] definitions of the normal," are at the core of multicultural philosophy across both countries (p. 225).

The irony, however, for Aboriginal and American Indian/Alaska Native students is that they do not consider themselves a part of these ethnic and cultural groups by virtue of being the first peoples of Turtle Island-North America. As the first inhabitants of Turtle Island, First Nations peoples had sophisticated cultural and linguistic educational practices that were grounded in communal contexts. In both contemporary American and Canadian educational contexts, however, First Nations students often learn in marginalized school environments and are depicted in public policy by deficit terms. These realities often serve to exploit an already underrepresented group. For these conditions to change, thus, Aboriginal students' experiences in practice and policy must be subject to critical discourse in order to inform teachers' pedagogical practices and understanding.

The theoretical perspectives of Michael Foucault are in fact instrumental considerations for teachers, administrators, and policy makers who are intent on understanding the governance of social policy. This paper offers an analysis of a seminal policy document related to Aboriginal education in Ontario, Canada, that appeals to educators and Aboriginal students across the continent. By considering specific elements of the Ontario First Nation, Métis, and Inuit Policy Framework (2007) from a Foucauldian perspective, the paper presents a policy discourse of knowledge, power, and identity from a multicultural education framework. Through Foucauldian theoretical perspectives, the paper creates alternate possibilities of confronting the ways to understand public educational policy-considered the purpose of multicultural education. A Foucauldian analysis of educational policy is particularly well-suited for public school educators to consider critically the systemic practices and calculated strategies of policy implementation. Specifically, the paper invites teachers, school 
administrators, district leaders, and policy makers to consider how public policy in one Canadian province (1) strategically situates Aboriginal peoples in a historical context, (2) exercises Foucauldian notions of power and care, and (3) potentially endorses the continued subjectification of Aboriginal peoples through recommendations of self-identification practices.

\section{Contextual Framework}

The Multiculturalism Act of 1988 called for the equal participation of all Canadian citizens in what is commonly referred to as an immigrant country. In Ontario, nearly $50 \%$ of its population consists of ethnicities and cultures of nonWestern European descent. The province has recently established an anti-racist policy to complement the provincial government's multicultural policies of 1977 (Ghosh \& Abdi, 2004). Notably, however, Canada's multicultural policy was not embraced by Aboriginal peoples because it does not acknowledge what they consider to be their fundamental rights as they were established through the various treaties and agreements with the European settlers.

In 1992 the Education Act was amended to commission provincial school boards to implement anti-racist and equity policies. The policy document related to Aboriginal education in Ontario, the Ontario First Nation, Métis and Inuit Policy Framework, was implemented in 2007 and recognizes that Aboriginal students have distinct learning preferences (see http://www.edu.gov.on.ca/eng/aboriginal/ fnmiFramework.pdf). The Framework, authored by the Ontario Ministry of Education (OME) as the provincial governing body in consultation with Aboriginal advisory groups, has "identified Aboriginal education as one of its key priorities" (p. 5). The Framework acknowledges that public school teachers, for the most part, are not prepared to address the historical, cultural, and linguistic variables that influence Aboriginal students' experiences in public school classrooms. It also recognizes the importance of engaging Aboriginal students in culturallyreceptive school environments that may foster more Aboriginal community involvement. The Framework identifies the importance of establishing inclusive school cultures that lend themselves to Aboriginal students' meaningful engagement in public schools. The Framework policy states that the strategies presented in the document are "based on a holistic and integrated approach to improving Aboriginal student outcomes" (p. 6). The Framework draws attention to Aboriginal students' learning preferences and provides public school teachers with various pedagogical and assessment strategies that reflect Aboriginal students' holistic approaches to learning. Among the objectives of the Framework is to heighten teachers' awareness of aligning Aboriginal students' epistemic worldviews with their socio-cultural traditions. In effect, the Framework obligates public schools to create "a space for Aboriginal initiatives...so that Indigenous ways of knowing can flourish and intercultural sharing can be practiced in a spirit of coexistence and mutual respect" (Castellano, 2000, p. 23).

The regional school administrators are primarily responsible for inservicing school principals who facilitate the professional development of their 
teachers in view of the Framework. The Framework identifies that Aboriginal cultures need to be distinguished within the multicultural mosaic of Ontario schools. Among its self-declared objectives, the Framework aims to close the achievement gap that separates the lower-achieving Aboriginal students from their mainstream student counterparts. The Framework stresses the need for the OME to collect data from provincial standardized tests to better assess Aboriginal student achievement.

\section{Theoretical Framework}

The impediments to Aboriginal peoples' entitlements in Canada have been discussed in various studies and government reports and by Aboriginal organizations (Assembly of First Nations, 1990; Battiste, 1997). It has been argued that mainstream Canadian society has not duly recognized Aboriginal epistemologies and traditions and as a result has enabled inequities to exist in power relationships between themselves and Aboriginal peoples (Neegan, 2005). It is an imbalance of power that consistently renders Aboriginal peoples in Canada into lower income brackets, higher unemployment and school drop-out categories, and a disproportionate dependency upon social welfare programs in comparison to mainstream Canadian society (Redefining Success, 2007; Satzewich, 1991). The situation is comparable to the plight of American Indians who also represent the highest dropout rates and the lowest college admissions (American Council in Education, 2002; Beaulieu, 2000). Furthermore, Aboriginal knowledge orientations are not represented in the dominant research traditions that are characteristic of Eurocentric paradigms (Iseke-Barnes, 2002; see also, Castellano, 2000; Dei, James, Karumanchery, James-Wilson, \& Zine, 2000).

Aboriginal peoples have demanded that their linguistic, cultural, and educational rights be honored by the federal and provincial governments; however, policy iniatiatives and political authorities have been somewhat unresponsive to these requests. The prominent Indigenous scholar, Marie Battiste (2002), identifies the challenge to "sensitize the Western consciousness of Canadians in general...to the colonial and neo-colonial practices that continue to marginalize and racialize" the unique character, rights, and relationships of Aboriginal peoples (p. 9).

A Foucauldian analysis of public educational policy in Ontario is both timely and relevant to conversations of multiculturalism, given the emerging neoliberal influence permeating educational policies in Canada and the United States as they relate particularly to standardized testing and public accountability. A Foucauldian perspective is an important analytical tool for policy and for Aboriginal peoples since it illuminates how knowledge, power, and identity are both presented and rationalized. Further, applying Foucault as an analytical lens underscores the continued colonial customs as identified in the literature. A Foucauldian analysis of specific elements of the OME document may foster connections for the reader between policy and practice as it exists in Ontario 
classrooms and elsewhere. Foucault's work, in particular, is instrumental in reminding us of the importance of having an openness to issues of teaching, learning, and multiculturalism that extends beyond our own personal thoughts and assumptions.

From a Foucauldian perspective, the provincial educational policy has adverse implications with respect to Aboriginal understandings of knowledge, power, and identity and may in fact further jeopardize the interests of Aboriginal learners and communities in light of multicultural practices. For Foucault (1972), knowledge is understood as "a group of elements, formed in a regular manner by discursive practice....[It is] the field of coordination and subordination of statements in which concepts appear, and are defined and transferred" (p. 182183). Foucault employed the metaphor of a game to refer to the play on truth by societal institutions and practices for the sake of exercising control over their constituents (Peters, 2003). Power, according to Foucault (1988), is the manner by which people attempt to determine the behavior of other individuals. Foucault believes that the concepts of knowledge and power are rendered into the dominant educational discourse to pose significant implications for peoples' identity (Hodgson, 2008). In essence Foucault cautions against those in positions of power who create the perception of crisis-like conditions in order to, in turn, be perceived as directly addressing the tensions. For Foucault, the inherent game in this tactic is to position those in power as willing to invest and tend to the apparent crisis, all the while establishing direct control over the conditions and stakeholders. It is this interrelationship of knowledge-construction, power, subjectivity, and identity that concerned Foucault and is precisely related to this discussion of educational social policy in Ontario (Ball, 1990; Morgan, 2005).

\section{Analysis}

Few would deny that multicultural policies in Ontario have focused educators' perspectives on issues related to ethno-cultural equity for students of non-Western European descent. In many respects such policies have brought to light the complexities of learning and achievement for students of multicultural backgrounds. By legitimizing their unique paradigms, educational policies have at the very least implied a consideration for multicultural students' academic engagement in public school cultures across Ontario and presumably beyond. To a varying extent, multicultural educational policies (when effectively translated into practice) have the potential to affirm students' uniqueness (Nieto, 2010). In some cases, as the literature attests, multicultural policy has contributed to culturally responsive pedagogy as a means of meaningfully incorporating students' backgrounds in the process of their learning (Gay, 2000; LadsonBillings, 2009).

For Aboriginal students, multicultural education policies have not contributed to improved learning environments in public school classrooms or 
cultures (Battiste, 2002). Documents like the OME's Framework recognize Aboriginal cultures as unique and describe Aboriginal learners' distinct learning preferences. Yet, a Foucauldian analysis of the Policy Framework suggests that the OME may be using crisis to support control over a demographic in this province and country that does not put credence into multicultural educational policy and practice. In Foucauldian terms, the OME has acknowledged the horrifying consequences of public educational institutions in Canada upon Aboriginal peoples. The Framework also identifies Aboriginal peoples' lower educational achievement and makes reference to the achievement gap that separates them from mainstream students. In doing so, however, the language of the Framework reinstates definitions of academic achievement in Eurocentric measures (standardized test scores). The OME Framework is presented in the context of genuine concern to respond to the aforementioned crises. The OME Policy Framework strategically situates Aboriginal peoples in a historical context, exercises Foucauldian notions of power and care, and endorses the continued subjectification of Aboriginal peoples.

\section{Situating Aboriginal Peoples Historically}

Foucault's theory of governmentality as it relates to educational policy focuses upon the discourse of the policy (the discursive field) to describe the context in which problems are identified and addressed (Lemke, 2001). To understand relationships of power within this discursive field Foucault proposed that subjects are subjected in their respective historical frameworks (Amigot \& Pujal, 2009).

In the Introduction of the Framework policy, the reference to the OME's "new approach to Aboriginal affairs" that will contribute to "a better future" induces an immediate connection to the actualization of historical realities that continue to have contemporary implications for Aboriginal peoples, including the proverbial achievement gap between Aboriginal and non-Aboriginal students across the continent, the disproportionately high levels of Aboriginal students dropping out of secondary school, and the generally high dependency upon social welfare services by the Aboriginal populations in Ontario (extending across Canada and the United States). Stated differently, the language of "a better future," as it is situated in the Framework, implicates for Aboriginal peoples upon a rather forgettable past, as it does a less than inspiring present. In describing the concept of governmentality, Foucault draws upon how different depictions of truth are related to political rationalities that "formulat[e] and justif[y] idealized schemata for representing reality, analyzing it and rectifying it" (Rose \& Miller, 1992, p. 179). The Framework's Introduction identifies the importance for teachers, principals, and school board administrators to understand that Aboriginal peoples' relationships with the public school system "has been strongly affected by residential school experiences and has resulted in

intergenerational mistrust of the education system" (p. 6). Positioning the 
historical realities of Aboriginal peoples' haunting experiences with colonial practices of education in such gentle and understated terms of references establishes a strategic historical truth that keeps the focus on Aboriginal peoples' perspectives and realities and not on the transgressions of the oppressors. The historical positioning of the impact of residential schools essentially repositions reality, in a Foucauldian sense, to lend greater legitimacy to the OME's commitment to change Aboriginal peoples' perspectives of public education for the better (see Dahlstedt, 2009). The focus becomes what the governing body will do for Aboriginal students.

The Framework's Vision Statement also has implications in light of Foucauldian thought. In the Vision Statement, the Framework alludes to the skills, knowledge, and attitude that Aboriginal students will acquire, as an outcome of the OME interventions, "to be socially contributive... and economically prosperous citizens" of Ontario (p. 7). Given the historical and contemporary realities often experienced by Aboriginal students and their communities in terms of lower achievement rates and high levels of social dependency, the Framework's Vision is indicative of the exercise of power to rationalize a crisis and self-declare proposed solutions (McDonald \& Marston, 2005). According to Foucault, this may be construed as a political strategy that positions historical truths to serve a political agenda that subtly imposes desired behavior upon the subjects that will make them socially contributive and economically prosperous citizens. In turn, the Framework's Policy Statement complements its Vision by re-articulating the OME's commitment to creating learning opportunities for Aboriginal students "that support improved academic achievement and identity building" (p. 7). Here again, the concept of Aboriginal identity is contextualized in its historical framework since identity itself is presented in a dependency context that requires OME strategies and intervention. This may be a means, in Foucauldian terms, of discursively presenting the concept of Aboriginal identity as a hidden form of standardization; stated differently, it may be construed as the OME's attempt to create Aboriginal identity according to mainstream political interests.

\section{Power and Care}

For Foucault (1988), power represents a means by which individuals strive to control the behavior of others. The exercise of power is defined as follows:

A total structure of actions brought to bear upon possible actions; it incites, it induces, it seduces, it makes easier or more difficult... it is nevertheless always a way of acting upon an acting subject or acting subjects by virtue of their acting or being capable of action. (Foucault, 1983, p. 220)

In the Framework's Introduction, the OME employs the language of "relationships" between themselves, district boards of education, and schools to describe how they as the governing body will "help" Aboriginal students "achieve their educational goals and close the gap in academic achievement with their 
non-Aboriginal counterparts" (p. 6). According to Foucauldian theory, the expressed interrelationship between power and agency is concerning. For example, the OME (as the dominant educational voice) self-positions themselves in the role of enabler-the partner who can "help" Aboriginal students achieve the goals articulated in the OME's own Policy Framework. Conversely, the Aboriginal student is resigned to the role of dependent requiring the assistance of the OME and public school officials to accomplish the goals articulated by the governing body. There is a Foucauldian danger in the manner by which the OME contextualizes Aboriginal students' positions in the Framework as individuals who are subjected to a dependent relationship. Aboriginal students are presented in the above statement as one body in juxtaposition to one other body - what the Framework identifies as "their non-Aboriginal counterparts" ( $p$. 6). It is noteworthy, in Foucauldian terms, that while the Aboriginal students are specifically identified, their "counterparts" are not. This positions Aboriginal students as what Foucault refers to as "the Other" and potentially serves to problematize this population in the same deficit terms that have historically subjectified them to inequitable conditions. Such a dubious distinction may present adverse consequences for Aboriginal students that can contribute towards "the existence of complex affective and unconscious processes-the psychic life of power" upon Aboriginal and non-Aboriginal students and communities (Amigot \& Pujal, 2009, p. 664). This may be construed as another example of an exercise of power that forces Aboriginal students and their communities to filter their educational and life experiences at the risk of further jeopardizing their already marginalized positions in greater society. It seems to problematize the conceptualization through which the notion of Aboriginal identity is produced and associated to behavior and action (Butler, 2002).

The Framework's Introduction also outlines the "holistic and integrated approaches to improving Aboriginal student outcomes" that identify a lack of awareness on the part of mainstream educators to meaningfully account for Aboriginal students' cultural and epistemic traditions (p. 6). Here too is evidence of the flexing of power by the dominant agency that makes explicit what Foucault identified as a series of actions that incite, induce, and seduce both the Aboriginal and non-Aboriginal reader into acknowledging the merit of the OME's commitment to heighten the attention and sensitivity of educators in order to better engage the Aboriginal learner in public schools and classrooms.

Similar to Foucault's (1979) concept of the exercise of power are his descriptions of pastoral methods of care. These are considered to be enabling methods of control by a dominant agency over their subjects and are generally perceived as redemptive in their intent to convert unhealthy subjects for the greater benefit of themselves and society at large (Vander Schee, 2008). The Framework envisions "healthy Aboriginal communities" made possible partly by OME goals and strategies to "create a better future for Aboriginal children and youth" (p. 5). Here, too, the underachieving, poverty-stricken, and welfare dependent Aboriginal child and youth are presented with an opportunity to be reformed by the caring governmental policy-maker for the greater good of all. As Fairclough (2003) suggests in relation to Foucault's notion of pastoral methods of 
care, "What is made explicit [in texts such as policy documents] is always grounded in what is left implicit. In this sense, making assumptions is one way of being intertextual" (p. 17). To extend this analysis, thus, the Framework seems to ignore the fact that "healthy Aboriginal communities" are influenced by a myriad of social conditions that in many instances are remotely distant from one's immediate control, thereby reducing the concept of health to one factor (Vander Schee, 2008).

In a similar vein, the Framework identifies strategies to "facilitate increased participation" by Aboriginal parents and communities to "support academic success" (p. 7). As is the case in the above example relating to health, this statement denies that the potential for Aboriginal students and communities to become engaged in public schooling practices is determined by other socioeconomic and socio-political realities. Consider, thus, the implications for Aboriginal communities and caregivers who cannot participate in the strategies outlined in the Framework. Would they not be further marginalized for rejecting the opportunities extended by the caring provider (the OME) that aims to improve the future of Aboriginal children and youth? It would seem that the "psychic life of power," extended by the OME's pastoral methods of care, accentuates the perceived unwillingness of the Aboriginal "Other" in mainstream society to take advantage of these policies of equity and fairness that recognize the needs of Aboriginal peoples. As a principle of the Framework, the OME "provides support and resources adapted to the specific needs" of Aboriginal students (p. 8). The OME is self-positioned as the power holder sensitive to the "needs" of the dependent Aboriginal student. The Aboriginal student is framed in a deficit context that informs the action of the provider. Under the sub-heading of Equity and Respect for Diversity, the Framework states that the "Government of Ontario creates and nurtures" positive academic environments for Aboriginal learners ( $p$. 8), further solidifying their position as caregiver. The Framework will, as a result, not only enhance Aboriginal student achievement but also lead to "high levels of public confidence" (p. 9). For those Aboriginal children, youth, caregivers, and communities who do not or cannot respond positively to the nurturing government policies because they still suffer from Aboriginal historical trauma, their socio-political representation risks being marked by an unwillingness to accept the assistance of the provider.

\section{The Subjectification of Aboriginal Peoples}

Foucauldian theory (1983) also focuses on the process by which people are positioned as subjects. For Foucault (1980), the concept of individual identity is best understood as an outcome of a relationship of power over people, movements, and forces. In the Framework's Policy Statement, the OME commits to increasing "the capacity of the education system to respond to the learning and cultural needs" of Aboriginal students attending public schools in Ontario (p. 7). In Foucauldian terms, the language of the Framework positions 
Aboriginal students as agents of their own subjection by the fact that they are resigned to the "Other" population of learners (separated from all other learners in public schools) who have "learning and cultural needs." In light of public perception, such a policy intention creates a subjective depiction of reality that frames the language of such governmental interventions as "necessary elements in achieving the Ministry's goals" and by extension, the goals of the larger society for Aboriginal students and communities (p. 9). As subjects of public policy interventions, Aboriginal learners are subjected to potentially dangerous strategic relationships with the governing body (Allen, 2002)-positions that have presumably become all too familiar for Native Peoples across the province and beyond.

Note too how the language of this policy document connotates neo-liberal notions that construe Aboriginal students as consumers who rely on the provider to address their unique needs (Leitner, Peck, \& Sheppard, 2007). According to neo-liberal ideology, monitoring targets and identifying outcomes creates quantifiable measures to audit and rank governmental interventions (Basu, 2009). The Framework sets "specific quantitative and qualitative performance measures" for each of their goals and suggests that "performance measures will be used to gauge the success of the implementation of the framework" (p. 10). These measures will, then, assess the "system effectiveness and First Nation, Métis, and Inuit student achievement" (p. 10). Given this neo-liberal exercise of power inherent in the discourse of the Framework, it may be of less surprise that the OME encourages school boards "to develop policies for voluntary, confidential Aboriginal student self-identification" to serve as a basis for collecting "reliable and valid data" in the form of standardized test scores. Yet, asking Aboriginal peoples to self-identify seems to further position them as subjects to be measured and regulated and to resign them to accept the same Eurocentric understanding of achievement and success as they are defined by mainstream society. The large-scale tests and provincial curriculum in Ontario are standardized interventions based on post-colonial values and worldviews. Hence, Aboriginal students and their communities are being asked to become agents of their own subjection, in Foucauldian terms, by consenting to the separate reporting of their test results according to measures that have been traditionally biased against Aboriginal epistemologies (see Fejes \& Nicoll, 2008).

Once again, the Framework refers to dominant discourses of power, success, and student achievement that in many respects violates Aboriginal peoples' assumptions about these worldviews. Also, by collecting "baseline data" (p. 10) of Aboriginal students' test results, the policy risks identifying Aboriginal students as the "Other" who is distinct from all the rest of students in Ontario (Foucault, 1985). Implicit in these policy intentions is a kind of false objectivity that reinforces the Other as dependent upon the nurturing and caring public body of government. The request for self-identification infers a social, intellectual, cultural, and political dichotomy that does little to enhance the spirit of multiculturalism in Ontario schools. The impact of presenting the achievement levels (test scores) of Aboriginal students independent of all other student 
populations confines Aboriginal learners and communities to familiar historical and oppressive circumstances (see Macleod \& Durrheim, 2002).

\section{Implications and Recommendations}

In the context of this analysis, self-identification may be construed as another means of subjectifying Aboriginal populations by regulating and measuring their outcomes. Peterson and Lupton (1996) emphasize Foucault's notion that the governing of subjects necessitates rendering their behavior into calculable terms. While the OME intends to measure the success of their interventions for the sake of planning and accountability, there is an inherent association to measures of governmental control. Confronted by their already marginalized status in Ontario society, Aboriginal peoples may be particularly vulnerable to these political strategies. One cannot help but wonder here too about the "psychic life of power" (as previously defined) that manifests in the consciousness of Aboriginal students and communities amidst the neo-liberal discourses of targets, achievement, and accountability. In effect, the OME is asking Aboriginal caregivers and communities to self-identify despite the historical consequences of formal public education that have contributed to the same achievement gap that the government is seeking to close. Alternatively, one can only speculate about the effectiveness of a more conciliatory approach to the policy discourse that might have informed the tax-paying public about the consequences of residential schooling on generations of Aboriginal peoples that still have contemporary implications. In this light, the public can better situate the significance of the policy Framework as a response to the devastating consequences of colonial education. The OME is soliciting the assistance of Aboriginal students to enact Eurocentric beliefs and values in public education.

Aboriginal education in Ontario is in crisis, as evidenced in achievement and graduation rates. By offering a Foucauldian perspective, this paper recommends that teachers, administrators, and policy makers critically examine policy like the OME's Framework and account for this crisis to support more control from the dominant political body over its subjects-Aboriginal students and their communities. Further, it is recommended that educators reflect upon the fact that although the amendment of the Education Act (1992) forced all district school boards in Ontario to enact multicultural policies, Aboriginal peoples found little consolation in anti-racist legislation that did not account for their tribal rights. When considering the OME's Framework from Foucault's (1980) perspective of governmentality, this analysis challenges educators to account for the complex influences that have historicized Aboriginal peoples and contributed to the process by which they are subjectified in their socio-political relationships with the dominant governing body (Elden, 2007). 


\section{Conclusion}

The OME Framework recognizes the historical and existing consequences of colonial education on Aboriginal peoples and uses the historical context to further legitimize their benevolence in terms of their crisis response to these deficit positions. Further, the governing body's exercise of power is articulated from the perspective of provider. The OME distinguishes that Aboriginal students have needs and that they can in fact nurture this student-demographic towards healthy and academically successful outcomes. By separating valid and reliable data according to Aboriginal and non-Aboriginal cohorts of students, the OME can target Aboriginal student achievement as part of their crisis response. All of these endeavors, as they are stated in the Framework, also serve to address measures of accountability to assure the tax-paying public in Ontario that the Aboriginal student population (in many respects, already considered as the "Other") is positively responding to these goals and initiatives. In effect, by contextualizing crisis to support control, a Foucauldian reading of the policy might suggest that the governing body is instilling various rationalities to normalize the behavior and practices of Aboriginal children, youth, and the communities from which they come (Pike, 2008). This seems a far cry from creating new possibilities in the ways we see the world-the very purpose of multicultural education to begin with.

Instead, policy makers might reconsider positioning policy in such contested discourses characteristic of normalized standards and empirical data. In doing so, Aboriginal educational policy could discuss Aboriginal student learning more in terms of the success to which they are entitled from the perspective of community interest that honors tradition, learning, and epistemic understandings. The community, in this conceptualization of policy, would keep all the stakeholders involved in Aboriginal education accountable to these interests. Such genuine partnerships between mainstream and community educators could succeed by using their mutual strengths and capacities to build sustainable educational policies and use relational accountability to encourage and mandate policy implementation.

\section{References}

Allen, A. (2002). Power, subjectivity, and agency: Between Arendt and Foucault. International Journal of Philosophical Studies, 10(2), 131-149.

American Council on Education. (2002). Nineteenth annual report on the status of minorities in higher education. Washington, DC: American Council on Education. 
Amigot, P., \& Pujal, M. (2009). On power, freedom, and gender. Theory and Psychology, 19(5), 646-669.

Apple, M. (2000). Official knowledge. New York: Routledge.

Assembly of First Nations. (1990). Towards linguistic justice for First Nations. Ottawa, ON: Assembly of First Nations Secretariat.

Ball, S. (1990). Foucault and education: Disciplines and knowledge. London: Routledge.

Basu, R. (2009). Phronesis through GIS: Exploring political spaces of education. The Professional Geographer, 61(4), 481-492.

Battiste, M. (1997). Enabling the autumn seed: Framing a decolonized curricular approach toward Aboriginal knowledge and education, paper presented at the CSAA Learned Society Conference, St. John's, Newfoundland, 8-11.

Battiste, M. (2002). Indigenous knowledge and pedagogy in First Nations education: A literature review with recommendations. Prepared for the National Working Group on Education. Ottawa, ON., 1-69.

Beaulieu, D. (2000). Comprehensive reform and American Indian education. Journal of American Indian Education, 39(2), 29-38.

Butler, J. (2002). What is critique? An essay of Foucault's virtue. In D. Ingram (Ed.), The political: Blackwell readings in continental philosophy (pp. 212- 228). Oxford, UK: Blackwell.

Castellano, M. B. (2000). Updating aboriginal traditions of knowledge. In Dei, G. J. S., Hall, B. L., \& Rosenberg, D. G. (eds.), Indigenous knowledges in global contexts: Multiple readings of our world (p. 21-44), Toronto, ON: University of Toronto Press.

Dahlstedt, M. (2009). Governing by partnerships: Dilemmas in Swedish education policy at the turn of the millennium. Journal of Education Policy, 24(6), 787801.

Dei, G. J. S., James, I. M., Karumanchery, L. K., James-Wilson, S., \& Zine, J. (2000). Removing the margins: The challenges and possibilities of inclusive schooling. Toronto, ON: Canadian Scholars Press.

Elden, S. (2007). Rethinking governmentality. Political Geography, 26(1), 29-33.

Fairclough, N. (2003). Analyzing discourse: Textual analysis for social research. New York: Routledge.

Fejes, A., \& Nicoll, K. (Eds.). (2008). Foucault and lifelong learning: Governing the subject. London: Routledge.

Foucault, M. (1972). The archeology of knowledge. New York: Pantheon Books.

Foucault, M. (1979). Discipline and punish. New York: Random House.

Foucault, M. (1980). Power/knowledge: Selected interviews and other writings, 1972-1977. New York: Pantheon Books. 
Foucault, M. (1983). Afterward: The subject and power. In H. Dreyfus \& P. Rabinow (Eds.), Michel Foucault: Beyond structuralism and hermeneutics ( $2^{\text {nd }}$ ed.) (pp. 208-226). Chicago: University of Chicago Press.

Foucault, M. (1985). History of sexuality: Vol. 2. The use of pleasure. New York: Random House.

Foucault, M. (1988). The ethic of care for the self as a practice of freedom. In J. Bernauer \& D. Rasmussen (Eds.), The final Foucault (pp. 1-20). Cambridge, MA: MIT Press.

Gay, G. (2000). Culturally responsive teaching. New York: Teachers College Press.

Ghosh, R., \& Abdi, A. A. (2004). Education and the politics of difference. Toronto: Canadian Scholars' Press.

Giroux, H. (1991). Postmodernism as border pedagogy. In H. Giroux (Ed.), Postmodernism, feminism, and cultural politics: Redrawing educational boundaries (pp. 217-256). Albany, NY: State University of New York Press.

Hodgson, N. (2008). Citizenship education, policy, and the educationalization of educational research. Educational Theory, 58(4), 417-434.

Iseke-Barnes, J. M. (2002). Aboriginal and indigenous people's resistance, the internet, and education. Race, Ethnicity and Education, 5(2), 171-198.

Ladson-Billings, G. (2009). The Dreamkeepers: Successful Teachers of African American Children. San Francisco, CA: Jossey-Bass.

Lee, E., Menkart, D., \& Okazawa-Rey, M. (1998) Beyond heroes and holidays: A practical guide to $\mathrm{k}-12$ anti-racist, multicultural education and staff development. Washington, DC: Network of Educators on the Americas, Washington.

Leitner, H., Peck, J., \& Sheppard, E.S. (2007). Contesting neoliberalism: Urban frontiers. New York: Guilford.

Lemke, T. (2001). The birth of bio-politics: Michel Foucault's lecture at the College de France on neo-liberal governmentality. Economy and Society, 30(2), 190207.

Macleod, C., \& Durrheim, K. (2002). Foucauldian feminism: The implications of governmentality. Journal for the Theory of Social Behavior, 32(1), 41-60.

McDonald, C., \& Marston, G. (2005). Workfare as welfare: Governing unemployment in the advanced liberal state. Critical Social Policy, 25(3), 374401.

Morgan, A. (2005). Governmentality versus choice in contemporary special education. Critical Social Policy, 25(3), 325-348. 
Neegan, E. (2005). Excuse me? Who are the first peoples of Canada? A historical analysis of Aboriginal education in Canada then and now. International Journal of Inclusive Education, 9(1), 3-15.

Nieto, S. (2010). Language, culture, and teaching. New York: Routledge.

Ontario Ministry of Education. (2007). Ontario First Nation, Métis, and Inuit Education Policy Framework. Toronto, ON: Aboriginal Education Office.

Peters, M. A. (2003). Truth-telling as an educational practice of the self: Foucault, Parrhesia and the ethics of subjectivity. Oxford Review of Education, 29(2), 207-226.

Peterson, A., \& Lupton, D. (1996). The new public health: Health and self in the age of risk. Thousand Oaks, CA: Sage.

Pike, J. (2008). Foucault, space and primary school dining rooms. Children's Geographies, 6(4), 413-422.

Redefining how success is measured in First Nations, Inuit and Métis learning. (2007). Report on Learning in Canada (Ottawa: Canadian Council on Learning).

Rose, N. (1999). Powers of freedom: Reframing political thought. Cambridge, UK: Cambridge University Press.

Rose, N., \& Miller, P. (1992). Political power beyond the state. British Journal of Sociology, 43(2), 172-205.

Satzewich, V. (1991). Deconstructing a nation: Immigration, multiculturalism and racism in '90s Canada. Halifax, NS: Fernwood.

Statistics Canada. (2003). Aboriginal peoples' survey_Initial findings: Well-being of the non-reserve Aboriginal population. Ottawa, ON: Author.

Statistics Canada. (2008). Aboriginal identity population by age groups, median age and sex, 2006 counts, for Canada and census metropolitan areas and census agglomerations-20\% sample data. Ottawa, ON: Author. Retrieved from http://www12.statcan.ca/english/census06/data/highlights/aboriginal/ index.cfm?Lang=E

Vander Schee, C. (2008). The politics of health as a school-sponsored ethic. Educational Policy, 22(6), 854-874. 